\title{
A SIMPLE NEPHELOMETRIC METHOD FOR THE DETERMINATION OF HUMAN SERUM BETA-LIPOPROTEIN ${ }^{1}$
}

\author{
By PETER BERNFELD, MORDECAI E. BẸTKOWWITZ, AṆD \\ VIRGINIA M. DONAHUE
}

\author{
(From the Department of Biochemistry and Nutrition, and the Cancer Research and Cance* \\ Control Unit of the Department of Surgery, Tufts University School of \\ Medicine, Boston, Mass.)
}

(Submitted for publication December 3, 1956; accepted May 23, 1957)

The measurement of lipoproteins in human serum is generally carried out by one of the following techniques: ultracentrifugal flotation (1-4); zone electrophoresis and subsequent staining of the lipids $(5,6)$; electrophoresis followed by cholesterol and/or phospholipid determinations on eluates of the supporting medium (7-9); and fractional precipitation of the serum proteins by ethanol at low salt concentrations, followed by lipid analyses of the fractions (10-13).

In the present paper, a new method of determination will be described which is specific for $\beta$-lipoprotein. This new method is distinguished from the above-mentioned ones by its marked simplicity and rapidity. It is based on a new principle: the fact that $\beta$-lipoprotein is the only protein of human serum which is precipitated by sulfated amylopectin at $\mathrm{pH} 8.6(14,15)$. At high dilutions of the serum, the resulting precipitate is highly dispersed, and its quantity can be estimated nephelometrically.

\section{METHOD}

Reagents. Sulfated amylopectin was obtained as the potassium salt (with 15 to 17 per cent $\mathrm{S}$ ), after treatment of corn amylopectin for five hours at $70^{\circ} \mathrm{C}$. with chlorosulfonic acid in pyridine (16). Amylopectin was prepared by the method of Schoch (17) and care was taken to remove all amylose. "Tris" buffer ${ }^{2}$ of $\mathrm{pH} 8.6$ at $23^{\circ}$ C. and of ionic strength $\mu=0.05$ was prepared according to Gomori (18).

Procedure. Serum is obtained by centrifugation of clotted blood in a clinical centrifuge at 2,000 rpm. Only markedly turbid sera have to be cleared, e.g., by centrifuging them for twenty minutes in a high speed attach-

1 This investigation was supported in part by research grant H-2025 from the National Institutes of Health, Public Health Service, and by an Institutional Grant of the American Cancer Society, Inc., New York, New York.

2 Trishydroxymethylaminomethane, purchased as Sigma 7-9 from Sigma Chemical Company, St. Louis, Missouri. ment of an International centrifuge at $20,000 \mathrm{rpm}^{3}$ An aliquot of $0.1 \mathrm{ml}$. of serum is diluted to $25 \mathrm{ml}$. with Tris buffer in a volumetric flask, and the turbidity of this solution is measured in $23 / 4$-inch fused black cell of a Fisher Nefluoro-Photometer. The solution is poured back into the volumetric flask and $0.15 \mathrm{ml}$. of a 0.1 per cent solution of sulfated amylopectin are added. After mixing the contents, the turbidity is determined in the same cell as before.

The instrument is adjusted to 100 per cent transmittance by the use of a $3 / 4$-inch fused black cell containing a freshly prepared turbidity reference solution. The latter is obtained by mixing $10 \mathrm{ml}$. of $0.16 \mathrm{mM} \mathrm{K}_{2} \mathrm{SO}_{4}, 2 \mathrm{ml}$. of $2 \mathrm{~N} \mathrm{HCl}$ and $2 \mathrm{ml}$. of $0.5 \mathrm{M} \mathrm{BaCl}_{2}$ containing also $1 \mathrm{Gm}$. of polyvinylalcohol ${ }^{4}$ per $100 \mathrm{ml}$. to maintain the $\mathrm{BaSO}_{4}$ in suspension. Since the $\mathrm{BaSO}$, slowly deposits in spite of the polyvinylalcohol, this solution cannot be used as a reference for longer periods of time than one hour after it has been prepared. Solutions of various high polymers can be advantageously used as stable turbidity standards, after they have been compared to a freshly prepared $\mathrm{BaSO}_{4}$ standard. A 1 per cent solution of PVM/MA, half amide, type 30,5 is well suited for this purpose since it does not change its turbidity for long periods of time.

The scattered light due to the turbidity is measured by reading the dial scale, termed per cent transmittance, and the concentration of $\beta$-lipoprotein is expressed as the difference in turbidity between the readings with and without added sulfated amylopectin. This value is called the nephelometric index of $\beta$-lipoprotein. ${ }^{\circ}$ A correction can be made for the turbidity of the sulfated amylopectin which is, however, very small. Recent experiments carried out with the Coleman Nephelometer using commercial nephelos standards have given excellent results.

${ }^{3}$ It has been found that centrifugation of normally clear serum at $20,000 \mathrm{rpm}$ for 45 minutes does not alter the results obtained with the method described herein.

4 Elvanol, duPont, grade 71-24.

- A copolymer of methyl vinyl ether and maleic anhydride, manufactured by The General Aniline and Film Corp., New York, New York.

${ }^{6}$ Symbols used in the statistical evaluations have been taken from Dixon, W. J., and Massey, F. J., An Introduction to Statitistical Analysis. New York, McGrawHill \& Co., 1951. 


\section{EXPERIMENTAL}

\section{Specificity of the reaction}

Previous experiments using the moving boundary technique of electrophoresis have clearly shown that among all serum proteins only $\beta_{1}$-globulin is precipitated by sulfated amylopectin (15). Additional evidence indicating the specificity of this reaction for $\beta_{1}$-globulin was obtained by an independent method. When human serum was fractionated by zone electrophoresis in a medium of starch granules, according to Kunkel and Slater (9), only the fractions with the mobility of $\beta_{1}$ globulin were found to produce turbidities with sulfated amylopectin (see Figure 1). All other fractions containing albumin, $\alpha_{1}^{-}, \alpha_{2^{-}}, \beta_{2^{-}}$and $\gamma$-globulin did not react more appreciably with the polysulfate ester than the eluates containing no protein (fractions -8 to -3 and 16 to 21 ). Further characterization of the precipitated $\beta_{1}$ globulin has revealed its lipoprotein nature with a

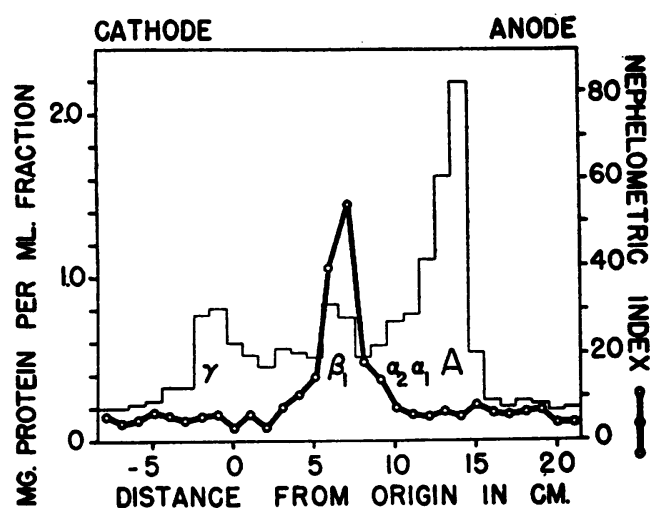

Fig. 1. Nephelometric Analyses of 18 Fractions Obtained From Human Serum by Zone ELECTROPHORESIS

Electrophoresis of $1.6 \mathrm{ml}$. of normal human serum in a square cuvette of $4.5 \mathrm{~cm}^{2}$ sectional area, using a supporting medium of potato starch granules, and Triscitrate buffer of $\mathrm{pH} 8.6$ and ionic strength 0.06 , electric field 3.3 volts per $\mathrm{cm}$. during 22 hours. One-cm. wide sections of the medium were eluted with $3 \mathrm{ml}$. of 0.9 per cent saline. Protein analyses (bar diagram) were performed on $0.1-\mathrm{ml}$. aliquots according to Lowry, Rosebrough, Farr, and Randall (19), A, $\alpha_{1}, \alpha_{2}, \beta_{1}$ and $\gamma$ being the portions of albumin and the corresponding globulins. The apparent cathodic migration of $\boldsymbol{\gamma}$-globulin was due to electro-osmotic flow. The nephelometric analyses (heavy line) were carried out on $2 \mathrm{ml}$.-aliquots in the presence of $300 \gamma$ crystalline bovine serum albumin to stabilize $\beta$-lipoprotein. ratio of lipide to polypeptide content (on a weight basis) of about 3 to 1 (15). The precipitated serum protein can, therefore, be considered to be $\beta$-lipoprotein.

\section{Stability of the turbidity}

Under the conditions of the procedure, the finely dispersed precipitate of $\beta$-lipoprotein with sulfated amylopectin neither deposits nor floats to the surface. Consequently, it is immaterial whether the nephelometric reading is carried out immediately after the addition of the reagent, or later (see Table I).

\section{Concentration of sulfated amylopectin}

The concentration of sulfated amylopectin used in this procedure is $150 \gamma$ per $25 \mathrm{ml}$. of reaction mixture with $0.1 \mathrm{ml}$. of serum; a maximal turbidity is obtained at this concentration of sulfated amylopectin (see Figure 2). Under these conditions, slight errors in the amount of sulfated amylopectin added would produce only negligible errors in the resulting turbidity.

\section{Nature of the precipitant}

Among all substances tested, sulfated amylopectin yields the highest turbidities and, hence, the greatest sensitivity of the method. The degree of sulfation of amylopectin is without importance for the nephelometric index, provided that at least two of the three available hydroxyl groups of the repeating unit in amylopectin are sulfated. Slightly lower turbidity values are obtained when the reagent is contaminated with sulfated amylose. This happens when amylose was not completely removed from amylopectin before sulfation.

TABLE I

Stability of the turbidity obtained after addition of sulfated amylopectin to serum

\begin{tabular}{cccc}
\hline \hline & \multicolumn{2}{c}{$\begin{array}{c}\text { Nephelometric index, read at different } \\
\text { time intervals after the addition of } \\
\text { sulfated amylopectin to serum }\end{array}$} \\
\cline { 2 - 4 } $\begin{array}{c}\text { Subject } \\
\text { number }\end{array}$ & $\begin{array}{c}\text { After } \\
15 \text { min. }\end{array}$ & $\begin{array}{c}\text { After } \\
75 \text { min. }\end{array}$ & $\begin{array}{c}\text { After } \\
24 \text { hours }\end{array}$ \\
\hline 1 & 52.5 & 52 & 51 \\
2 & 44 & 46.5 & 46.5 \\
3 & 48 & 47 & 45 \\
4 & 51.5 & 52.5 & 52.5 \\
5 & 48 & 47 & 47 \\
\hline
\end{tabular}




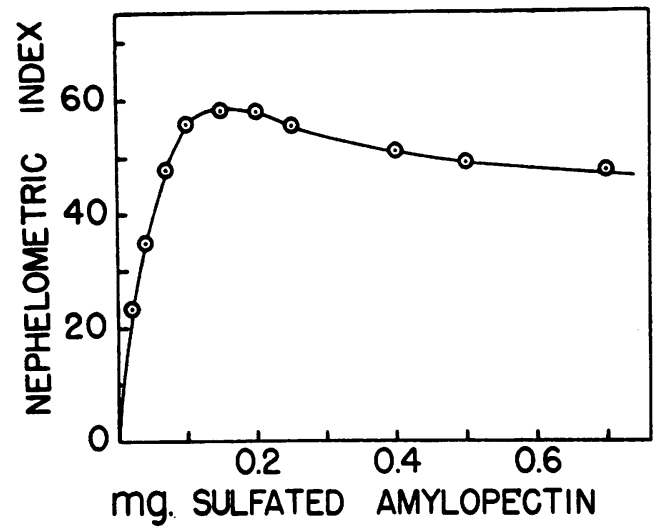

Fig. 2. Relationship of Nephelometric Index to Concentration of Sulfated Amylopectin, When Whole Serum is Used as the Source of LIPoprotrin

Each sample contained $0.1 \mathrm{ml}$. of serum (from a single batch) and the amount of sulfated amylopectin indicated on the abscissa, in a total volume of $25 \mathrm{ml}$. Tris buffer. With the use of preparations of isolated $\beta$-lipoprotein, a maximum of the nephelometric index was found at 0.03 mg. sulfated amylopectin per sample.

\section{Linearity of the reaction}

The nephelometric index has been found to be proportional to the concentration of $\beta$-lipoprotein (see Figure 3). The lipoprotein used in this experiment was obtained by ultracentrifugation of normal human serum for 22 hours in a No. 40 head of the Spinco Model $\mathrm{L}$ ultracentrifuge at $40,000 \mathrm{rpm}$, average of $105,400 \times \mathrm{G}$, in a saline density tube (20). Fractional withdrawal of the solution from the density gradient tube yielded a fraction (at a density of the solution of $d=1.030$ ) containing lipoprotein with 70.5 per cent total lipides and a ratio of total cholesterol to phospholipide of 1.23 (on a weight basis), and which migrated as a single peak on moving boundary electrophoresis, with a mobility of 3.5 to $3.7 \times 10^{-5}$ $\mathrm{cm}^{2}$ sec. $^{-1}$ volt $^{-1}$.

\section{Sensitivity and precision of the method}

According to the data in Figure 3, the method is sensitive to less than $100 \gamma$ of $\beta$-lipoprotein per sample. When preparations of isolated $\beta$-lipoprotein are assayed, the precision of the method is characterized by a standard error of estimate of 5.85 , calculated from the data in Figure 3. With whole serum, the precision is much higher (see Figure 4), apparently because of a stabilization of

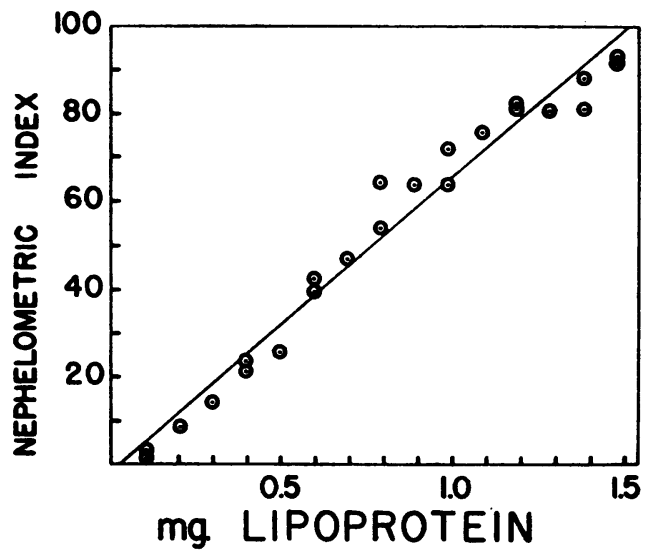

Fig. 3. Relationship of NePHeLOMEtric INDEX to ConCENTRATION OF $\boldsymbol{\beta}$-LIPOPROTEIN

Each sample contained the amount of $\beta$-lipoprotein indicated on the abscissa, $0.3 \mathrm{mg}$. crystalline bovine serum albumin to stabilize the lipoprotein and $0.03 \mathrm{mg}$. sulfated amylopectin in a total volume of $25 \mathrm{ml}$. of Tris buffer. The concentration of $\beta$-lipoprotein was calculated by adding up the concentrations of total polypeptide (according to Lowry and co-workers [19]) and total lipide. This value was within 5 per cent of the dry weight of the preparation after exhaustive dialysis against distilled water. The solid line represents the estimated regression line.

the lipoprotein by its environment of serum proteins. Thus, a standard error of estimate of 1.61 is obtained from the data in Figure 4, with a confidence interval of \pm 3.4 to \pm 3.6 nephelometric units over the whole range of observation, for a level of significance of $\alpha=5$ per cent.

\section{Influence of inherent turbidity of serum}

The inherent turbidity of the serum sample does not influence the nephelometric lipoprotein index, since the results have been found to be unchanged when turbid sera are cleared by centrifugation. It is recommended, however, to clear highly turbid serum samples in order to prevent a shifting of the turbidity readings into too high levels.

\section{Comparison of the nephelometric index with elec- trophoretic and ultracentrifugal data}

Table II shows the relationship between the turbidity obtained upon addition of sulfated amylopectin to serum at high dilutions (nephelometric index) and the amount of $\beta_{1}$-globulin precipitated at higher concentrations of serum. The latter 


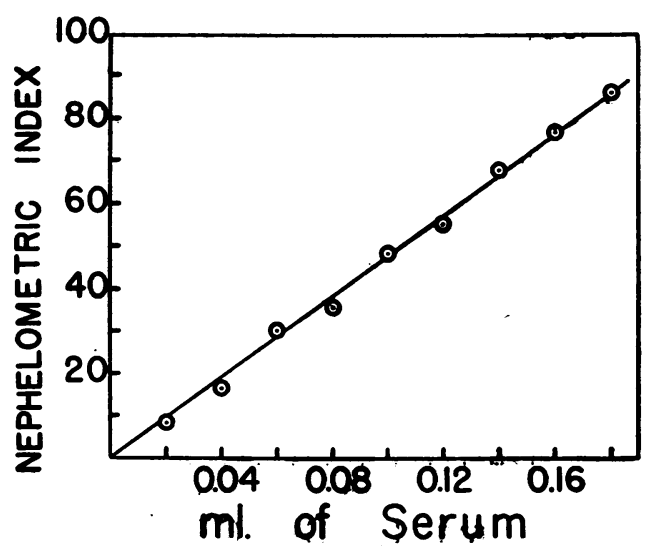

Fig. 4. RELATIONSHIP OF NEPHELOMETRIC INDEX TO Amount of Serum

Each sample contained the amount of serum indicated on the abscissa and $0.15 \mathrm{mg}$. sulfated amylopectin in a total volume of $25 \mathrm{ml}$. Tris buffer.

data were calculated from the difference in absolute area measurements of the electrophoretic patterns (21) obtained with and without the addition of sulfated amylopectin. Due to the lipoprotein nature of the precipitate (15), a correction had to be made for the difference in refractive indices between simple proteins and lipoproteins of low densities (22). Thus, the protein concentration which would have been obtained for simple proteins has been multiplied by a factor of 1.09 , representing the ratio of the refractive index in-

TABLE II

Comparison of electrophoretic and nephelometric data on the effect of addition of sulfated amylopectin to serum

\begin{tabular}{cccc}
\hline \hline $\begin{array}{c}\text { Subject } \\
\text { number }\end{array}$ & $\begin{array}{c}\text { Decrease in } \\
\text { k-globulin from } \\
\text { electrophoretic } \\
\text { analyses* }\end{array}$ & $\begin{array}{c}\text { Increase in } \\
\text { turbidity } \\
\text { (nephelometric } \\
\text { index)t }\end{array}$ & $\begin{array}{c}\text { Ratio of } \\
\text { electro- } \\
\text { phoretic to } \\
\text { nephelometric } \\
\text { values }\end{array}$ \\
\hline & (mg.per 100 ml.) & & \\
1 & $490 \pm 50 \ddagger$ & 42 & $11.7 \pm 1$ \\
2 & $490 \pm 50$ & 42 & $11.7 \pm 1$ \\
3 & $480 \pm 50$ & 38 & $12.6 \pm 1$ \\
4 & $640 \pm 50$ & 49.5 & $12.9 \pm 1$ \\
5 & $490 \pm 50$ & 41 & $12.0 \pm 1$ \\
6 & $390 \pm 50$ & 35.5 & $11.0 \pm 1$ \\
7 & $510 \pm 50$ & 43.5 & $11.7 \pm 1$ \\
8 & $490 \pm 50$ & 39 & $12.6 \pm 1$ \\
Mean & & & $12.0 \pm 1$ \\
\hline
\end{tabular}

* Determined from the difference in absolute area measurements of the electrophoretic patterns, according to Tiselius and Kabat (21), and corrected for the refractive index increment of lipoglobulin (see text).

$\dagger$ For definition of nephelometric index, see text.

$\ddagger$ Standard error of the measurement. crements of simple proteins to $\beta$-lipoprotein (23). Statistical evaluation of the data in Table II yields regression coefficients $A=41.3$ and $B=$ 0.0826 , with a standard error of the estimate $\mathrm{S}_{\mathrm{y.x}}=2.36$. It was assumed in this evaluation that the regression line would pass through the origin. This assumption appears to be experimentally justified, since the nephelometric index was found to be zero for a serum which has been treated with sulfated amylopectin and from which the resulting precipitate was removed by centrifugation, from which the excess sulfate ester was then removed by its precipitation as the barium salt, and from which the excess of barium ion was finally removed by dialysis. Further statistical evaluation has shown that there is excellent agreement between these two methods. In fact, a $t$ value of 6.31 was obtained in testing the hypothesis that there is no relationship; such a hypothesis would be acceptable only if $t$ were between -2.45 and 2.45 (level of significance $\alpha=2.5$ per cent, d.f. $=6)$.

Data for lipoprotein analyses by the nephelometric method and by the ultracentrifugal flotation technique ${ }^{7}$ are compared in Table III, and their statistical evaluation is presented in Table IV. No significant agreement between nephelometric measurements and any of the routinely computed ultracentrifugal Sf ranges can be observed.

\section{DISCUSSION}

\section{Quantitative interpretation of the nephelometric index}

The new nephelometric method has been applied to whole serum as well as to isolated $\beta$-lipoprotein. The use of purified lipoprotein has presented certain difficulties, due mainly to the instability of lipoprotein preparations. These difficulties have been largely overcome by the addition of bovine serum albumin to the lipoprotein sample. On the basis of data obtained with isolated $\beta$-lipoprotein preparations (Figure 3 ), the nephelometric index would have to be multiplied by a factor of 14.65 in order to convert it into a value indicating $\beta$-lipoprotein in $\gamma$ per sample,

7 The ultracentrifugal experiments were performed by Dr. A. J. Barak, Department of Biochemistry, The University of Nebraska, College of Medicine, Omaha, Nebraska. 
TABLE III:

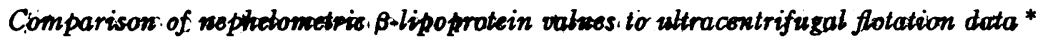

\begin{tabular}{|c|c|c|c|c|c|c|}
\hline \multirow{2}{*}{$\begin{array}{l}\text { Subject } \\
\text { nưmber }\end{array}$} & \multirow{2}{*}{$\begin{array}{l}\text { Nephelometric } \\
\text { index }\end{array}$} & \multicolumn{5}{|c|}{$\begin{array}{l}\text { Ultracentrifugal flotation values for lipoproteins } \\
\text { (mtg. pef } 100 \text { mt.) }\end{array}$} \\
\hline & & Sf 0-12 & Sf $12-20$ & St $20^{2} 100$ & Sf $100-400$ & St $0-400$ \\
\hline $\begin{array}{r}9 \\
10 \\
11 \\
12 \\
13 \\
14 \\
15 \\
16 \\
17 \\
18 \\
19 \\
20\end{array}$ & $\begin{array}{l}43 \\
49.5 \\
43 \\
39 \\
46 \\
45 \\
53.5 \\
43 \\
40 \\
49.5 \\
50.5 \\
46.5\end{array}$ & $\begin{array}{l}284 \\
267 \\
262 \\
250 \\
348 \\
309 \\
360 \\
351 \\
311 \\
306 \\
367 \\
345\end{array}$ & $\begin{array}{l}22 \\
42 \\
64 \\
17 \\
25 \\
27 \\
34 \\
25 \\
27 \\
27 \\
15 \\
27\end{array}$ & $\begin{array}{r}51 \\
34 \\
100 \\
29 \\
54 \\
12 \\
56 \\
49 \\
96 \\
34 \\
34 \\
74\end{array}$ & $\begin{array}{l}15 \\
12 \\
15 \\
15 \\
12 \\
12 \\
17 \\
17 \\
17 \\
12 \\
22 \\
17\end{array}$ & $\begin{array}{l}372 \\
355 \\
441 \\
311 \\
439 \\
360 \\
467 \\
442 \\
451 \\
379 \\
438 \\
463\end{array}$ \\
\hline
\end{tabular}

* The ultracentrifugal experiments were performed by Dr. A. J. Barak, Department of Biochemistry, University of Nebraska College of Medicine, Omaka, Nebraska.

and by the same factor to yield mg. of $\beta$-lipoprotein per $100 \mathrm{ml}$. of serum, provided a sample of $0.1 \mathrm{ml}$. of serum has been used for the analyses.

Another way of interpreting quantitatively the nephelometric index is the use of electrophoretic data presented in Table II in which the nephelometric index is compared to the decrease of $\beta_{1}$ globulin upon addition of sulfated amylopectin to serum. Thus, multiplication of the nephelometric index by 12.0 , the mean value of the ratio of electrophoretic to nephelometric results, or by 12.1, the reciprocal of the regression coefficient $(B=$ 0.0826 ), also yields a $\beta$-lipoprotein value in $\mathrm{mg}$. per $100 \mathrm{ml}$. of serum.

Due to the marked heterogeneity of serum lipoproteins with respect to molecular weight, density, lipid content and lipid constituents, the various methods for their determination do not cover exactly the same range of individual lipoproteins and, hence, they do not yield. identical results. In the light of these considerations, the diserepancy between the two factors of 14.65 and 12.1 is not significant. We tend, however, to give preference to the value of 12.1 since the factor of 14.65 has been obtained with the use of a lipoprotein preparation which may contain diverse impurities.

\section{Sources of error}

The main source of error in this procedure is the interference with extraneous turbid materials, e.g., dust or traces of any water insoluble matter which might remain in the glassware after cleaning. For this reason, the above-described procedure provides that the two nephelometric readings, i.e., with and without precipitant, are carried out on one single sample of diluted serum, rather than on two different aliquat portions. Thus, the

TABLE IV

Statistical comparison between nephelometric, flotation and electrophoretic data of. lipaprotein analyses.

\begin{tabular}{|c|c|c|c|c|c|c|c|c|}
\hline \multirow[b]{2}{*}{ Statistic } & \multicolumn{7}{|c|}{ Sf-Range of flotation } & \multirow{2}{*}{$\begin{array}{l}\text { Electros. } \\
\text { phoresis }\end{array}$} \\
\hline & $0-12$ & $12-20$ & $0-20$ & $20-100$ & $0-100$ & $100-400$ & $0-400$ & \\
\hline $\begin{array}{l}A^{*} \\
B^{*} \\
S_{y . x} \dagger \\
t \neq\end{array}$ & $\begin{array}{l}45.7 \\
0.055 \\
4.0 \\
1.87\end{array}$ & $\begin{array}{l}45.7 \\
0.016 \\
4.7 \\
0.17\end{array}$ & $\begin{array}{l}45.7 \\
0.067 \\
3.8^{\prime} \\
2.24\end{array}$ & $\begin{array}{l}45.7 \\
-0.046 \\
4.5 \\
0.91\end{array}$ & $\begin{array}{l}45.7 \\
0.025 \\
4.4 \\
0.94\end{array}$ & $\begin{array}{l}45.7 \\
0.113 \\
5.3 \\
0.21\end{array}$ & $\begin{array}{c}45.7 \\
0024 \\
4.15 \\
0.99\end{array}$ & $\begin{array}{c}41.3 \\
0.0826 \\
2.36 \\
6.31\end{array}$ \\
\hline
\end{tabular}

* Regression coefficients.

Standard! error of estimate:
$t$ value of statistical significance. No agreement exists between the data in each column and the nephelometric data if $t$ is between -2.23 and +2.23 for the flotation values $(\alpha=2.5$ per cent, d.f. $=10)$; and for $t$ between -2.45 and +2.45 for the electrophoretic data $(\alpha=2.5$ per cent; d.f. $=6)$.

8 From data in Table II. 
presence of the same amount of an additional turbidity before and after the addition of precipitant does not affect the results, since only the difference between these two readings is important for the analysis of $\beta$-lipoprotein. The turbidity reference solution of barium sulfate is, however, subject to such extraneous factors, and it is recommended to compare at least eight individual reference solutions to each other, to eliminate those having a very high turbidity and to average the readings of the remainder of them. When stable reference solutions are used, e.g., 1 per cent PVM/MA solution, as in routine determinations, their turbidity has to be compared to the barium sulfate standard only once. The use of commercial nephelos standards with the Coleman Nephelometer does not present these inconveniences.

Since fibrinogen also produces a turbidity with sulfated amylopectin, this plasma protein might interfere with the $\beta$-lipoprotein determinations in some pathological cases where the normal clotting of fibrinogen is impaired.

\section{Specificity of the method}

While there appears to be no doubt that the nephelometric method is specific for $\beta_{1}$-globulins (see Figure 1) and that that portion of the latter protein fraction which precipitates with sulfated amylopectin is a lipoprotein with over 70 per cent lipide content, it remains questionable whether the nephelometric method covers all of what is generally called $\beta_{1}$-lipoprotein or only a certain part of it. The latter assumption does not appear likely, however, since the nephelometric data in Table III, when multiplied by the factor 12.1, yield $\beta$-lipoprotein concentrations which are even higher than those found for the corresponding Sf $0-400$ group.

Though it is generally believed that the $\beta$-lipoprotein fraction corresponds to the low density lipoproteins, as determined by ultracentrifugal flotation (24), no agreement between nephelometric index of $\beta$-lipoprotein and any of the four Sf groups of lipoproteins was found (see Tables III and IV), while the agreement between nephelometric index and the Sf 0-20 group appears to be barely significant. This lack of agreement is not surprising, however, since the delimitations between these Sf groups have been chosen arbi- trarily. The increase in the $t$ value from Sf $0-20$ and its consequent decrease to Sf $0-12$ would make it appear as if there existed another group of Sf, not routinely computed, which would more closely agree with the nephelometric data, e.g., an arbitrary group of Sf 5-20.

A comparison of nephelometric lipoprotein index with total cholesterol values in about 30 subjects did not indicate a relation between these two factors. When the results of these two determinations were compared to each other in the same subject, however, remarkable parallelism was observed in many individuals.

\section{SUMMARY}

1. A new method for the determination of $\beta$-lipoprotein in human serum has been developed. It is based on the nephelometric measurement of a finely-dispersed precipitate of $\beta$-lipoprotein with sulfated amylopectin at $\mathrm{pH}$ 8.6.

2. This method is simple, rapid and requires as little as $0.1 \mathrm{ml}$. of serum. The sensitivity of the method is less than $100 \gamma$ of $\beta$-lipoprotein per sample, and the precision is given by a standard error of estimate of 1.61 , when $\beta$-lipoprotein is determined in serum.

3 . The specificity of this method for $\beta$-lipoprotein has been established by zone and moving boundary electrophoretic techniques.

4. No agreement between $\beta$-lipoprotein by nephelometry and ultracentrifugally-determined lipoprotein of any of the commonly computed flotation rate groups has been found. The nephelometric method is liable, however, to agree with a certain range of lipoproteins not commonly calculated, e.g., Sf 5-20.

\section{ACKNOWLEDGMENT}

We are grateful to Dr. A. J. Barak for carrying out the ultracentrifugal study, and to Mrs. Sylvia Jacobson and Stuart Cook for valuable technical assistance.

\section{REFERENCES}

1. Gofman, J. W., Lindgren, F., Elliott, H., Mantz, W., Hewitt, J., Strisower, B., and Herring, V., The role of lipids and lipoproteins in atherosclerosis. Science, 1950, 111, 166.

2. Pedersen, K. O., On a low-density lipoprotein appearing in normal human plasma. J. Phys. Chem., 1947, 51, 156.

3. Havel, R. J., Eder, H. A., and Bragdon, J. H., The 
distribution and chemical composition of ultracentrifugally separated lipoproteins in human serum. J. Clin. Invest., 1955, 34, 1345.

4. Hillyard, L. A., Entenman, C., Feinberg, H., and Chaikoff, I. L., Lipide and protein composition of four fractions accounting for total serum lipoproteins. J. Biol. Chem., 1955, 214, 79.

5. Jencks, W. P., and Durrum, E. L., Paper electrophoresis as a quantitative method: The staining of serum lipoproteins. J. Clin. Invest., 1955, 34, 1437.

6. Swahn, B., Studies on blood lipids. Scandinav. J. Clin. \& Lab. Invest., 1953, 5, Supp1. 9.

7. Langan, T. A., Durrum, E. L., and Jencks, W. P., Paper electrophoresis as a quantitative method: Measurement of alpha and beta lipoprotein cholesterol. J. Clin. Invest., 1955, 34, 1427.

8. Fasoli, A., Electrophoresis of serum lipoproteins on filter-paper. Acta med. Scandinav., 1953, 145, 233.

9. Kunkel, H. G., and Slater, R. J., Zone electrophoresis in a starch supporting medium. Proc. Soc. Exper. Biol. \& Med., 1952, 80, 42.

10. Cohn, E. J., Gurd, F. R. N., Surgenor, D. M., Barnes, B. A., Brown, R. K., Derouaux, G., Gillespie, J. M., Kahnt, F. W., Lever, W. F., Liu, C. H., Mittelman, D., Mouton, R. F., Schmid, K., and Uroma, E., A system for the separation of the components of human blood: Quantitative procedures for the separation of the protein components of human plasma. J. Am. Chem. Soc., 1950, $72,465$.

11. Oncley, J. L., Gurd, F. R. N., and Melin, M., Preparation and properties of serum and plasma proteins. XXV. Composition and properties of human serum $\beta$-lipoprotein. J. Am. Chem. Soc., 1950, 72, 458.

12. Russ, E. M., Eder, H. A., and Barr, D. P., Proteinlipid relationships in human plasma. I. In normal individuals. Am. J. Med., 1951, 11, 468.

13. Herbst, F. S. M., Lever, W. F., Lyons, M. E., and Hurley, N. A., Effects of heparin on the lipopro- teins in hyperlipemia. An electrophoretic study of the serum alpha and beta lipoproteins after their separation by fractionation of the plasma proteins or ultracentrifugal flotation. J. Clin. Invest., 1955, $34,581$.

14. Bernfeld, P., and Nisselbaum, J. S., Reaction of human serum $\beta$-lipoglobulin with macromolecular polysulfate esters. Federation Proc., 1956, 15, 220.

15. Bernfeld, P., Donahue, V. M., and Berkowitz, M. E., Interaction of human serum $\beta$-lipoglobulin with polyanions. J. Biol. Chem., 1957, 226, 51.

16. Tipson, R. S., Sulfonic esters of carbohydrates. Advances in Carbohydrate Chem., 1953, 8, 107.

17. Schoch, T. J., The fractionation of starch. Advances in Carbohydrate Chem., 1945, 1, 247.

18. Gomori, G., Buffers in the range of $\mathrm{pH} 6.5$ to 9.6 . Proc. Soc. Exper. Biol. \& Med., 1946, 62, 33.

19. Lowry, O. H., Rosebrough, N. J., Farr, A. L., and Randall, R. J., Protein measurement with the Folin phenol reagent. J. Biol. Chem., 1951, 193, 265.

20. Oncley, J. L., and Mannick, V. G., Studies on human plasma lipoproteins. Trans. of 5 th International Congress of Blood Transfusion, Paris, 1954, 890896.

21. Tiselius, A., and Kabat, E. A., An electrophoretic study of immune sera and purified antibody preparations. J. Exper. Med., 1939, 69, 119.

22. Hanig, M., and Shainoff, J. R., Specific refractive increment of serum lipoproteins obtained by flotation. J. Biol. Chem., 1956, 219, 479.

23. Armstrong, S. H., Budka, M. J. E., Morrison, K. C., and Hasson, M., Preparation and properties of serum and plasma proteins. XII. The refractive properties of the proteins of human plasma and certain purified fractions. J. Am. Chem. Soc., 1947, 69, 1747.

24. Jones, H. B., Gofman, J. W., Lindgren, F. T., Lyon, T. P., Graham, D. M., Strisower, B., and Nichols, A. V., Lipoproteins in atherosclerosis. Am. J. Med., 1951, 11, 358. 